\title{
TEKNIK AKROSTIK UNTUK MENINGKATKAN KEMAMPUAN MENGHAFAL UNSUR-UNSUR GOLONGAN UTAMA (A) DI TABEL SISTEM PERIODIK UNSUR
}

\author{
Mohamad Mahfud \\ SMAN 1 Singosari, Malang, Jawa Timur \\ Email: mohammad.mahfud.satrawi@gmail.com
}

\begin{abstract}
Abstrak
Hafalan nama unsur- unsur golongan utama (A) secara urut di tabel Sistem Periodik Unsur (SPU), sering lupa atau ingat beberapa unsur tapi tidak urut, sehingga guru menjumpai kesulitan dalam mengajarkan materi yang terkait dengan sifat-sifat keperiodikan unsurunsur golongan utama (A) tersebut. Guru dituntut untuk mampu membantu siswa untuk menggunakan teknik akrostik agar dapat menghafal unsur-unsur golongan utama (A). Penelitian ini bertujuan meningkatkan kemampuan menghafal unsur-unsur golongan utama (A) secara urut pada tabel sebagai modal untuk memahami sifat-sifat keperiodikan unsur. Metode Penelitian yang digunakan adalah Penelitian Tindakan Kelas (PTK). Berdasarkan analisis data selama siklus I dan II dapat disimpulkan bahwa telah terjadi peningkatan hasil belajar menjadi 89,10 pada siklus I dan 93,50 pada siklus II.
\end{abstract}

Kata kunci: teknik akrostik, kemampuan menghafal, nama unsur-unsur

\section{Latar Belakang}

Pada umumnya siswa mengalami kesulitan untuk menghafal unsur- unsur golongan utama dalam sistem periodik unsur. Hal ini terjadi karena dalam golongan utama terdiri dari delapan kelompok mulai dari golongan I A (alkali) sampai dengan golongan VIII A (gas inert/mulia), harus urut dan sesuai dengan golongannya. Jika terbalik atau tidak sesuai dengan kelompok golongannya maka akan terjadi kekeliruan dalam memahami sifat fisik dan sifat kimianya. Jika terjadi kekeliruan dalam menentukan sifat fisik maupun kimia akibat tidak atau kurang hafal maka kekeliruan berikutnya akan salah dalam memprediksi sifat- sifat unsur dan hasil reaksi. Menghafal unsur- unsur golongan utama tadi akhirnya menjadi modal dasar untuk menentukan sifat-sifat unsur seperti jari-jari atom, sifat pembentukan asam basa, kelogaman, kereaktifan, afinitas dan keelektronegatifan dan hasil reaksinya.
Biasanya siswa menghafal masih menggunakan sistem konvensional dengan mengandalkan otak kiri. Unsur- unsur dalam sistem periodik unsur itu dibaca berulang- ulang sambil ditulis, ditulis dan dilafal sesuai dengan nama asli, urutan dan golongannya. Akan tetapi yang terjadi hafalannya hanya bersarang dalam memori jangka pendek (immediate memory) atau hanya sampai pada memori kerja (working memory) yang hanya berfungsi pada saat akan menghadapi ulangan harian. Sedikit sekali yang sampai pada memori jangka panjang (long time memory) yang bermanfaat sampai ujian nasional bahkan untuk anak cucu. Hal ini disebabkan teknik menghafal yang konvensional dan tidak memberdayakan otak kanan. Oleh karena itu teknik menghafal akrostik yang memfungsikan otak kanan menjadi penting agar hafalan terhadap unsur- unsur menjadi memori jangka panjang. Teknik akrostik adalah suatu teknik menghafal dengan 
cara mengambil huruf depan dari materi yang ingin dihafal kemudian huruf depan ini digabungkan dan dibuat suatu singkatan atau cerita yang lucu. Otak kanan akan memunculkan kreativitas dalam menyusun akrostik dan imajinasi dalam menyusun kata- kata dan kalimat. Dengan demikian menggunakan teknik akrostik merupakan kegiatan yang tepat dan diharapkan dapat meningkatkan hafalan siswa terhadap unsur-unsur golongan utama dalam sistem periodik unsur. Data yang peneliti peroleh dari hasil ulangan harian kelas X-IPA E/17 di SMAN 1 Singosari diperoleh rata-rata 53,10, masih jauh dari KKM sebesar 70.

Berdasarkan latar belakang kesulitan siswa pada umumnya dalam menghafal, maka dapat dirumuskan suatu hipotesis yaitu: Pemberian teknik akrostik meningkatkan kemampuan menghafal unsur- unsur golongan utama (A) dalam Sistem Periodik Unsur (SPU) bagi siswa kelas X-IPA E/17 SMAN 1 Singosari Kabupaten Malang Provinsi Jawa Timur. Hasil penelitian ini diharapkan dapat bermanfaat bagi siswa yaitu: minat menghafal unsur-unsur dalam sistem periodik unsur meningkat, dapat lebih mengenal teknik menghafal yang memfungsikan otak kanan, dan dapat menghargai orang lain dengan memperhatikan peningkatan kemampuan menghafal dengan berbagai teknik. Bagi guru (peneliti) yaitu: memberikan kegiatan teknik pembelajaran alternatif yang disesuaikan dengan kemampuan siswa dan materi pelajaran yang membutuhkan teknik tertentu dalam menghafal, memberikan kegiatan yang tepat dan bermakna bagi siswa yang mengalami kesulitan dalam menghafal unsur- unsur dalam sistem periodik unsur, dan memberikan inspirasi untuk digunakan dalam materi- materi yang harus dihafal dengan urutan dan klasifikasi yang tepat. Bagi Sekolah yaitu: memberikan masukan tentang kegiatan teknik pembelajaran yang dapat mengatasi kesulitan menghafal siswa, sebagai bahan untuk mengambil kebijakan yang berkaitan dengan proses belajar dan mengajar bagi siswa, dan sarana pemberdayaan untuk meningkatkan kerjasama dan kreativitas guru. Bagi Peneliti yang lain yaitu: mendapatkan informasi hasil penelitian dengan pemberian teknik akrostik, mendapatkan informasi peluang untuk diadakan penelitian lebih lanjut, dan mendapatkan informasi untuk mengembangkan kegiatan teknik pembelajaran bagi siswa dalam mengatasi kesulitan untuk menghafal.

\section{Landasan Teori}

\section{Memori dan Hafalan}

Riset mutakhir di bidang memori menunjukkan bahwakitamemilikilebih dari satu jenis memori. Masing-masing memori mempunyai mekanisme penyimpanan informasi yang unik dan terhubung satu dengan yang lainnya. Pengaktifan satu jenis memori akan memicu memori yang lainnya. Informasi mengenai satu hal yang sama dapat disimpan di berbagai tempat penyimpanan memori yang berlainan. Bila kita dapat menyimpan informasi ini secara multimemori, kita akan sangat mudah memanggil kembali informasi ini saat kita membutuhkannya.

Dalam penyimpanan informasi ada tiga macam memori yang kita kenal, yaitu memori jangka pendek (immediate memory), memori kerja (working memory) dan memori jangka panjang (long time memory). Perbedaan dari tiga macam memori ini terletak pada tempat dan rentang waktu penyimpanannya. Memori jangka pendek menyimpan informasi begitu singkat yaitu sekitar 15-30 detik, sedangkan memori kerja dapat menyimpan informasi dalam hitungan jam dan memori 
jangka panjang dapat seumur hidup.

Teknik memori adalah teknik memasukkan informasi ke dalam otak yang sesuai dengan cara kerja otak (brain based technique). Jika teknik yang digunakan sejalan dengan cara otak beroperasi dan berfungsi, maka hal itu akan meningkatkan efektivitas dan efisiensi otak dalam menyerap dan menyimpan informasi. Daya serap otak tergantung bagaimana kita memasukkan informasi ke dalam otak. Jika kita memasukkannya sesuai dengan kerja otak maka informasi itu akan disimpan dalam jangka waktu yang lama (long time). Otak sangat suka akan hal yang bersifat: tidak masuk akal, penuh warna, multi sensori, lucu, melibatkan emosi, melibatkan irama atau musik, tindakan aktif, gambar tiga dimensi, hidup, aktif, menggunakan asosiasi, imajinasi, humor, simbol, nomor dan urutan. Semakin kita dapat menggunakan poin yang disukai otak kita dan menyeimbangkan penggunaan kedua belah otak kanan-kiri, maka semakin maksimal daya serap dan kemampuan otak menyimpan informasi. Jika penggunaan otak kiri dalam menghafal mengalami kesulitan, kita dapat menggunakan otak kanan untuk merancang teknik cara menghafal kita yang kreatif dan imajinatif. Teknik menghafal dengan Akrostik

Banyak teknik yang dapat digunakan untuk menghafal. Teknik konvensional yang biasa digunakan hanya sampai pada memori jangka pendek dan memori kerja serta jarang yang sampai tersimpan di memori jangka panjang. Salah satu teknik tersebut adalah teknik akrostik. Teknik Akrostik adalah teknik menghafal dengan cara mengambil huruf depan materi yang ingin dihafal, kemudian huruf depan ini digabungkan dan dibuat suatu singkatan atau cerita yang lucu. Misalnya kita mau menghafal urutan nama planet dari posisi yang terdekat dengan matahari hingga planet terjauh di dalam tata surya yaitu : Merkurius, Venus, Bumi, Mars, Jupiter, Saturnus, Uranus, Neptunus dan Pluto menjadi singkatan yang lucu : Main Volley Ball Membuat Jantung Sehat Untuk Nenek Peot. Begitu pula untuk menghafal unsur- unsur golongan IVA dalam sistem periodik unsur yang terdiri dari Carbon (C), Silikon (Si), Germanium (Gn), Stannium $(\mathrm{Sn})$ dan Plumbum $(\mathrm{Pb})$ dapat dibuat kalimat yang lucu : Cewek Sinting Genit Senang Plembungan. Untuk dapat membuat akrostik yang lucu dan menarik membutuhkan kreativitas. Akan tetapi jika kita telah berhasil menghafal dengan teknik ini, dijamin informasi akan tersimpan di memori jangka panjang, sebab jika kita lupa tinggal mengulang akrostiknya bukan nama planet atau unsurnya.

\section{Metodologi}

\section{Lokasi dan Subyek Penelitian}

Penelitian ini dilaksanakan di kelas X-IPA E/17 SMAN 1 Singosari Kabupaten Malang Jawa Timur. Subyek yang diteliti adalah siswa SMAN 1 Singosari Malang kelas X-IPA E/17 semester 1 tahun pelajaran 2017/2018 sebanyak 36 siswa dengan rincian 14 siswa laki- laki dan 22 siswa perempuan.

\section{Metodologi Penelitian}

Metode penelitian secara umum diartikan sebagai cara ilmiah untuk memperoleh data dengan tujuan dan kegunaan tertentu, dimana cara ilmiah disini berarti suatu kegiatan penelitian itu didasarkan pada ciriciri keilmuan yaitu rasional, empiris, dan sistematis. Dalam penelitian ini, metode yang digunakan adalah metode penelitian tindakan kelas. Penelitian Tindakan Kelas disebut juga Classroom Action Reasearch. Penelitian tindakan kelas (PTK) merupakan 
suatu bentuk yang bersifat reflektif dengan melakukan tindakan-tindakan tertentu agar dapat memperbaiki dan meningkatkan praktik-praktik pembelajaran di kelas secara profesional. Beberapa bentuk penelitian tindakan kelas. Menurut Oja dan S. Mulyan (1989:3) ada empat bentuk penelitian tindakan kelas, yaitu:

1. Guru sebagai peneliti

2. Penelitian tindakan kolaboratif

3. Simultan integrasi

4. Administrasi sosial ekperimental

Adapun bentuk penelitian tindakan kelas yang digunakan disini adalah bentuk yang pertama, yaitu PTK yang memandang guru sebagai peneliti. Dalam bentuk ini tujuan utama PTK adalah untuk meningkatkan praktik-praktik pembelajaran di kelas dimana guru terlibat langsung dalam perencanaan, tindakan, dan refleksi.

Beberapa model desain PTK yang dapat dikembangkan guru kelas diantaranya:

1. Model Kurt Lewin

2. Model Kemmis dan Mc. Taggart

3. Model John Elliot

4. Model Hopkins

Penelitian model PTK yang digunakan adalah model Kemmis dan Mc. Taggart yang merupakan pengembangan dari konsep dasar yang diperkenalan oleh Kurt Lewin. Desain Kemmis dan Mc. Taggart menggunakan model yang dikenal dengan sistem spiral refleksi yang terdiri dari empat komponen yaitu perencanaan (planning), tindakan (action), pengamatan (observing), dan refleksi (reflection).

\section{Prosedur (Rancangan Penelitian)}

Penelitian ini dilakukan menggunakan Penelitian Tindakan Kelas yang terdiri dari dua siklus. Masing-masing siklus meliputi: Perencanaan, tindakan, pengamatan dan refleksi. Pelaksana penelitian tindakan kelas ini adalah guru kimia X-IPA E/17 dan berkolaborasi dengan guru kimia kelas X-IPA D/17. Guru kelas X-IPA D/17 dalam hal ini sebagai observer dan guru peneliti yang melakukan kegiatan proses belajar mengajar disertai pemberian teknik akrostik.

Sebelum pelaksanaan penelitian tindakan kelas berlangsung diadakan observasi, guru observer mengikuti secara langsung masuk kelas saat proses belajar mengajar berjalan. Hal ini untuk mengetahui situasi dan kondisi kelas secara lebih jelas serta perubahan- perubahan apa yang terjadi pada siswa.

Tabel 1. Perencanaan Penelitian

\begin{tabular}{lll}
\hline Pelaksana & \multicolumn{1}{c}{ Jenis Kegiatan } & \multicolumn{1}{c}{ Keterangan } \\
\hline Guru & Mendesain program pembelajaran ten- & RPP-3 telah dilakukan Minggu sebel- \\
Peneliti & tang sistem keperiodikan unsur- unsur & umnya dengan metode diskusi, tetapi \\
& (RPP-3a) dan RPP-3b dengan perbai- & hasil evaluasi tidak mencapai KKM, \\
& kan jika pada RPP-3a belum mencapai & sehingga didesain RPP-3a dengan \\
& KKM dengan teknik akrostik. & memakai teknik akrostik. \\
\cline { 2 - 3 } & $\begin{array}{l}\text { Memberikan pretest ulang tentang sis- } \\
\text { tem keperiodikan unsur termasuk unsur- }\end{array}$ & $\begin{array}{l}\text { Memberikan hasil pretest untuk dinilai } \\
\text { unsur dari golongan I A sampai dengan }\end{array}$ \\
& $\begin{array}{l}\text { golongan VIII A. } \\
\end{array}$
\end{tabular}




\begin{tabular}{|c|c|c|}
\hline Pelaksana & Jenis Kegiatan & Keterangan \\
\hline & $\begin{array}{l}\text { Memberikan teknik akrostik untuk } \\
\text { menghafal unsur-unsur golongan utama } \\
\text { dalam sistem periodik unsur dari golon- } \\
\text { gan IA sampai dengan golongan VIII A. }\end{array}$ & $\begin{array}{l}\text { Masing-masing siswa diminta untuk } \\
\text { membuat akrostik untuk unsur- unsur } \\
\text { golongan IA sampai dengan VIIIA ses- } \\
\text { uai dengan kreatifitas dan imajinasinya } \\
\text { masing-masing. }\end{array}$ \\
\hline & Memberikan post test I & $\begin{array}{l}\text { Post test yang diberikan berkaitan den- } \\
\text { gan hafalan siswa tentang unsur utama } \\
\text { dari IA sampai dengan VIII A disertai } \\
\text { sistem keperiodikan unsur berdasarkan } \\
\text { hafalannya tersebut. }\end{array}$ \\
\hline & Menganalisis hasil post test I & $\begin{array}{l}\text { Menganalisis bersama guru peneliti, } \\
\text { jika belum mencapai KKM dilanjutkan } \\
\text { dengan siklus II. }\end{array}$ \\
\hline \multirow[t]{2}{*}{$\begin{array}{l}\text { Guru } \\
\text { Observer }\end{array}$} & $\begin{array}{l}\text { Mengamati perlakuan siklus II dengan } \\
\text { RPP-3b. }\end{array}$ & $\begin{array}{l}\text { Mengadakan refleksi dengan mem- } \\
\text { berikan analisis pada treatmen yang } \\
\text { diberikan peneliti berupa masukan dan } \\
\text { perbaikan. }\end{array}$ \\
\hline & & $\begin{array}{l}\text { Data yang diperoleh sebagai bahan } \\
\text { refleksi lebih lanjut. }\end{array}$ \\
\hline
\end{tabular}

Langkah- langkah Pemberian Teknik Akrostik

a. Guru peneliti menjelaskan teknik akrostik.

b. Guru peneliti membimbing siswa membuat akrostik untuk unsurunsur golongan utama sesuai dengan kreativitas dan imajinasinya masingmasing (siklus I)

c. Guru peneliti memotivasi siswa untuk membuat akrostik sifat- sifat keperiodikan unsur- unsur seperti kecenderungan jari- jari atom, energi ionisasi, afinitas elektron, keelektronegatifan dan kelogaman (siklus II)

d. Guru memberi contoh kongkrit tentang akrostik yang ada di materi ajar.

e. Agar lebih bersemangat instruksi diberikan dalam perintah langsung.

f. Setelah kegiatan pemberian teknik akrostik, guru peneliti mengadakan evaluasi pengenalan dan pemahaman dengan memberikan post test yang sebelumnya telah diadakan pre test.

\section{Pelaksanaan Siklus}

\section{Siklus Pertama}

a.1. Waktu : 2 x 45 menit

a.2. Mengadakan pre test tentang unsurunsur golongan utama (A)

a.3. Memberikannya kepada guru observer untuk mengoreksi

a.4. Tindakan yang dilakukan adalah memberikan pengajaran dengan memberikan teknik akrostik sesuai RPP-3a di atas

a.5. Memotivasi siswa untuk mencoba teknik akrostik

a.6. Memberikan post test. Jika hasil post test belum mencapai KKM maka dilanjutkan dengan siklus II

a.7. Mengadakan refleksi bersama guru observer

a. 8. Mengadakan perbaikan pada RPP3a menjadi RPP-3b tanpa merubah metodenya

a.9. Mengulangi pada siklus II dengan materi sifat keperiodikan unsur. 


\section{Siklus Kedua}

b.1. Waktu, 2 x 45 menit

b.2. Tindakan yang dilakukan adalah sama dengan siklus I, dalam pembuatan akrostik sifat keperiodikan unsurunsur

b.3. Memotivasi siswa untuk membuat akrostik yang lebih lucu

b.4. Memberikan post test pengenalan dan pemahaman Sifat Keperiodikan Unsur pada akhir kegiatan

b.5. Mengadakan refleksi bersama guru observer.

Tabel 2. Persentase Keberhasilan Siswa

\section{Pembahasan} pre test) :

\begin{tabular}{llll}
\hline No. & \multicolumn{1}{c}{ Keadaan siswa } & Jumlah & Persentase \\
\hline 1. & Berhasil mengenal dan memahami sifat keperiodikan unsur & 3 & $8,33 \%$ \\
\hline 2. & Kurang berhasil mengenal dan memahami sifat keperiodikan & 5 & $13,89 \%$ \\
\hline 3. & Tidak berhasil mengenal dan memahami sifat keperiodikan & 28 & $77,78 \%$ \\
\hline & Jumlah & 36 & $100 \%$ \\
\hline
\end{tabular}

Berdasarkan tabel di atas maka dapat disimpulkan bahwa pengenalan dan pemahaman sifat keperiodikan unsur belum berhasil mencapai KKM, dengan model pembelajaran kooperatif learning. Dengan demikian maka dibutuhkan pengajaran remedial dengan metode yang tepat dan bermakna. Metode pengajaran yang ditawarkan peneliti adalah metode Pretest-Posttest dengan Teknik Akrostik. Pelaksanaan Penelitian Tindakan Kelas
Setelah diadakan identifikasi awal dari seluruh siswa kelas X-IPA E/17 SMAN 1 Singosari Kabupaten Malang, pada saat pemberian pengenalan dan pemahaman sifat keperiodikan unsur pada semester I dengan pendekatan saintifik dengan model pembelajaran cooperatif learning yang tertuang dalam RPP-3, maka diperoleh data sebagai berikut (berdasarkan hasil

ini akan melalui beberapa siklus, artinya jika pada siklus I belum tercapai titik jenuh (KKM) maka akan dilanjutkan pada siklussiklus berikutnya. Setiap siklus mengikuti tahapan-tahapan sebagai berikut, yaitu: tahap perencanaan, pelaksanaan, pengamatan, analisis dan refleksi.

Berdasarkan pengamatan dan hasil Pre test dan Post test maka diperoleh data sebagai berikut :

\begin{tabular}{|c|c|c|c|c|c|c|}
\hline \multirow{2}{*}{ No. } & \multirow{2}{*}{ Keadaan siswa } & \multirow{2}{*}{$\begin{array}{l}\text { Respon } \\
\text { Terhadap } \\
\text { Teknik } \\
\text { Akrostik }\end{array}$} & \multicolumn{2}{|c|}{$\begin{array}{l}\text { Hasil Pre test/ } \\
\text { Post test }\end{array}$} & \multicolumn{2}{|c|}{ Prosentase } \\
\hline & & & Pre test & Post test & $\begin{array}{l}\text { Pre } \\
\text { test }\end{array}$ & $\begin{array}{c}\text { Post } \\
\text { test }\end{array}$ \\
\hline 1. & $\begin{array}{l}\text { Berhasil mengenal/ menghafal } \\
\text { dan memahami sifat keperiodikan } \\
\text { unsur }\end{array}$ & Baik & 35 & 36 & $0 \%$ & $100 \%$ \\
\hline 2. & $\begin{array}{l}\text { Kurang berhasil mengenal dan } \\
\text { memahami sifat keperiodikan } \\
\text { unsur }\end{array}$ & Baik & 1 & - & $2,77 \%$ & - \\
\hline \multirow[t]{2}{*}{3.} & $\begin{array}{l}\text { Tidak berhasil mengenal dan } \\
\text { memahami sifat keperiodikan } \\
\text { unsur }\end{array}$ & Baik & - & - & - & - \\
\hline & Jumlah & Baik & 1 siswa & 36 siswa & $2,77 \%$ & $100 \%$ \\
\hline
\end{tabular}


Berdasarkan tabel di atas (siklus I) dapat diketahui bahwa terdapat 35 siswa $(97,22 \%)$ yang tuntas dan terdapat 1 siswa $(2,78$ $\%)$ yang belum tuntas dengan nilai ratarata sebesar 89,10. Secara klasikal telah mengalami ketuntasan karena melebihi $97,22 \%$, walaupun secara individual masih ada satu siswa yang belum tuntas sehingga dilanjutkan ke siklus II.

\section{Hasil Siklus II}

Hasil kegiatan dari siklus II yang berupa hasil tes pada akhir pertemuan dapat dilihat pada tabel berikut: untuk mengenal dan memahami sifat keperiodikan unsur-unsur ternyata siswa kelas X-IPA E/17 SMAN 1 Singosari lebih mudah dan ada peningkatan signifikan. Hal ini dibuktikan dengan terjadinya kenaikan jumlah siswa yang berhasil mengenal dan memahami sifat keperiodikan unsur-unsur dan dapat menghafal unsur-unsur golongan utama dari 3 siswa $(8,33 \%)$, meningkat menjadi 35 siswa $(97,22 \%)$ pada siklus pertama, sebab yang satu siswa yang belum mencapai KKM sedangkan pada siklus II mencapai ketuntasan penuh (100\%).

\begin{tabular}{|c|c|c|c|c|c|c|}
\hline \multirow{2}{*}{ No. } & \multirow{2}{*}{ Keadaan siswa } & \multirow{2}{*}{$\begin{array}{c}\text { Respon } \\
\text { Terhadap } \\
\text { Teknik } \\
\text { Akrostik }\end{array}$} & \multicolumn{2}{|c|}{$\begin{array}{c}\text { Hasil Pre test/ } \\
\text { Post test }\end{array}$} & \multicolumn{2}{|c|}{ Prosentase } \\
\hline & & & Pre test & Post test & $\begin{array}{l}\text { Pre } \\
\text { test }\end{array}$ & $\begin{array}{c}\text { Post } \\
\text { test }\end{array}$ \\
\hline 1. & $\begin{array}{l}\text { Berhasil mengenal/menghafal dan } \\
\text { memahami sifat keperiodikan unsur }\end{array}$ & Baik & 35 & 36 & $0 \%$ & $100 \%$ \\
\hline 2. & $\begin{array}{l}\text { Kurang berhasil mengenal dan } \\
\text { memahami sifat keperiodikan unsur }\end{array}$ & Baik & 1 & - & $2,77 \%$ & - \\
\hline 3. & $\begin{array}{l}\text { Tidak berhasil mengenal dan } \\
\text { memahami sifat keperiodikan unsur }\end{array}$ & Baik & - & - & - & - \\
\hline \multicolumn{2}{|c|}{ Jumlah } & Baik & 1 siswa & 36 siswa & $2,77 \%$ & $100 \%$ \\
\hline
\end{tabular}

Berdasarkan tabel di atas dapat diketahui bahwa terdapat 36 siswa (100\%) yang tuntas dengan nilai rata- rata sebesar 93,50. Secara klasikal maupun individual telah mengalami ketuntasan. Sedangkan terkait dengan respons terhadap teknik akrostik (afektif) adalah baik, sebab mereka sangat antusias dan menyenangkan. Untuk nilai psikomotor dalam membuat akrostik baik pada golongan IA sampai dengan VIIIA maupun sifat keperiodikan unsurunsur mereka mampu membuatnya sesuai dengan imajinasi masing-masing.

\section{Kesimpulan}

Bertolak dari Penelitian Tindakan Kelas (PTK) pemberian Teknik Akrostik
Pemberian teknik akrostik bagi siswa merupakan salah satu teknik alternatif untuk mengenal dan memahami sifat keperiodikan unsur sekaligus untuk menghafal unsur-unsur golongan utama, oleh karena itu perlu diberikan teknik-teknik lain untuk mempermudah pengenalan dan pemahaman pada materimateri kimia yang lain.

Pemberian teknik akrostik ini telah memotivasi dan memberi suasana gembira bagi siswa sehingga dapat mempermudah pengenalan dan pemahaman siswa terhadap sifat keperiodikan unsur-unsur dan kemampuan menghafal unsur-unsur golongan utama dalam tabel sistem periodik unsur. 


\section{Saran- saran}

Memperhatikan hasil kesimpulan di atas maka disarankan bagi (1) guru untuk menggunakan teknik akrostik dalam menghafal, mengenal dan memahami sifat keperiodikan unsur-unsur dalam tabel sistem periodik unsur (SPU); (2) siswa, untuk lebih efektif dan efesien dalam menghafal, mengenal dan memahami sifat keperiodikan unsur dengan menggunakan teknik akrostik; (3) peneliti lain, dapat memanfaatkan hasil penelitian untuk penelitian lebih lanjut; dan (4) sekolah, mengimbaskan pada mata pelajaran lain melalui MGMP tingkat sekolah.

\section{Daftar Rujukan}

Chernow, Fred B (Penerjemah Rina Buntaran). (2001). The Sharper Mind. Jakarta : PT. Gramedia Pustaka Utama.

Creswell, J. 2014. Penelitian Kualitatif dan Desain Riset: Memilih di antara Lima Pendekatan. Yogyakarta: Pustaka Belajar.

De Porter, Bobbi dan Mike Hernacki. (1992). Quantum Learning, Bandung :Kaifa.

Gunawan, Adi.W., (2006). Genius Learning Strategy, Jakarta: Gramedia Pustaka Utama

Hermann, Douglas J. (Penerjemah T. Zaini Dahlan). (1996). Super Memory. Jakarta : Pustaka Dellapratasa.

Jensen, Eric \& Karen, Markowitz. (Penerjemah Lala Herawati Dharma). Otak Sejuta Gigabyte. Bandung : Kaifa.

Nasional, Departemen Pendidikan, (2013). Kurikulum 2013, Jakarta.

Nasution, S., (2000). Didaktik Asas-Asas Mengajar, Jakarta: Bumi Aksara, , cet. 2.
Sport B. Downa Markova. (2003). Born

ToBe Smart, Jakarta : Prestasi Pustaka Raya.

Suharsimi Arikunto. (1996). Prosedur Penelitihan Suatu Pendekatan Praktek. Yogyakarta: Rineka Cipta.

Sugiyono. (2009). Metode Penelitihan Kuntitatif, Kualitatif dan R\&D. Bandung: Alfabeta.

Sukmadinata, Nana Syaodih. (2003). Landasan Psikologi Proses Pendidikan, Bandung: Remaja Rosda Karya, 2003, cet. 1

Usman, H. (2004). Metodologi Penelitian Sosial, Jakarta : PT Bumi Aksara. 